To further investigate neonatal thyroid function IR-TRH was studied by RIA after plasma chacoal extraction. TSH and IR-TRH were measured in paired maternol cord samples and in $40 \mathrm{~min}$ and $24 \mathrm{~h}$ old neonates.

$\begin{array}{lcccc} & \text { Mother } & \text { Cord } & 40 \mathrm{~min} & 24 \mathrm{~h} \\ \mathrm{n}= & 11 & 11 & 11 & 6 \\ \mathrm{TRH} & 12.4 & 50.3 & 48.4 & \mathbf{4 2 . 7} \\ \mathrm{pg} / \mathrm{ml} & \pm 7.5 & +19.2 & \pm 13.7 & \pm 24.1 \\ \pm \mathrm{SD} & & & & \\ \mathrm{TSH} & +8.2 & 12.6 & 120.2 & \pm 13.9 \\ \mu \mathrm{U} / \mathrm{ml} & \pm 6.0 & \pm 7.2 & \pm 47 & \end{array}$

IR-TRH was higher in cord than in maternal plasma ( $p<0.001)$ and remained constant during the first $24 \mathrm{~h}$ of $\mathrm{life}$. No correlation with TSH was observed. IR-TRH was undetectable in 3 to 6 months old normol infants. In 2 anencephalics, cord IR-TRH was 15 and $8 \mathrm{pg} / \mathrm{ml}$ and no acute variation of TSH was observed during the first $2 \mathrm{~h}$ of life.

In conclusion : High plasma IR-TRH was observed in human neonates at birth. Low values in anencephalic babies is in favour of the hypothalamic origin of this moterial. studfed to determine whether heritable HGH deficiency is due to alteration in the HGH/HPL gene cluster on human chromosome 17 . Sibjects included 5 with multiple pituitary hormone deficiency, 3 with bioinactive HGH, 8 with 1solated HGH deficiency without affected siblings and 2 pairs of siblings with autosomal recessive isolated $\mathrm{HGH}$ deficiency. DNA fragments containing $\mathrm{HGH}$ and HPL-related gene sequences were detected by Southern blot hybridization to a 32P-labeled HPL CDNA probe. HGH and HPL genes exist in multiple, non-allelic forms. They are not resolved in Eco RI digests but can be distinguished in Bam HI and Bgl II digests. We have detected 3 variant polymorph1c Bg1 II restriction patterns which are traceable through pedigrees and can be used to test for physical linkage of HGH deficiency to HGH/HPL gene cluster variation. Al1 HGH/HPL restriction patterns found in hypopituitary individuals were also found in normals. Thus, there were no instances in which HGH deficiency could be attributed to deletion of an $\mathrm{HGH}$ gene. Also, discordance for Bg1 II restriction patterns in 2 siblings with autosomal recessive HGH deficiency provided evidence against HGH gene mutation as the cause of the disease.

M.MAES* and J.M.KETELSLEGers* (Intr. by P. Malvaux). Unité de Diabète et Croissance,University of Louvain. Brussels, Belg1um.

Ontogenesis of somatogenic and lactogenic liver receptors in male and female rats.

To study the regulation of the liver somatogen $1 \mathrm{c}(\mathrm{GH})$ and lactogen1c (PRL) receptors during development, their number and aff1nity were determined at weekly intervals in male and female rats, the results were correlated with growth velocity and the hormonal changes 1nduced by puberty. The GH and PRL binding sites of liver homogenates were analyzed using $125_{\text {I-bovine and }}{ }^{125}$ I-ovine PRL. In the males, the PRL receptors were present at day $21 \quad 2.0 \pm 0.5$ pmoles/liver; mean \pm 1 S.E., $n=5)$, reached a peak at day $35 \quad(9 \pm 2$, $\mathrm{n}=53$, then decreased to be undetectable at day 63. In the femoles, their evolution was similar until day 35 , thereafter, a four-fold 1ncrease occurred, a plateau being reached at day $49(52 \pm 8 ; n=5)$. The number of $\mathrm{GH}$ receptors exhib1ted a progressive 1ncrease in males (day 21: $9 \pm 1, n=5$; day 120: 47 $\pm 9, n=5$ ) and females (day 21. $5 \pm 1, n=5$, day $120: 73 \pm 10, n=5)$. At the time of pubertal growth spurt the mean number of $\mathrm{GH}$ receptors was equal to $50 \%$ of the adult values. The affinity (Ka) of GH and PRL receptors showed no signif1cant change with age and sex (DGH: $0.61 \pm 0.03 \times 10^{9} \mathrm{~m}^{-1}$, OPRL: $0.93 \pm$ $\left.0.06 \times 10^{9} \mathrm{M}^{-1}, \mathrm{n}=60\right)$. These data suggest that in the male, the pubertal rise of testosterone inhibits the PRL receptors, while in the female the surge of estradiol 1nduces a sharp increase of these receptors. The GH receptors do not appear to be regulated by gonedal steroids.

\section{A monoclonal antibody against anti-müllerian hormone}

Anti-müllerian hormone (AMH) has been partially purified from incubation medium of calf fetal testes (Picard and Josso, 1981). It produces müllerian regression in organ culture and contains one major radioactive protein, when testes have been incubated in the presence of tritiated fucose. Identity between AMH and this label led marker protein has been postulated, and, in consequence, the latter has been used to screen hybridomas for anti-AMH activity. Splenocytes of a BALB/C mouse, injected with partially purified AMH, produced 297 hybridomas after fusion with myeloma cells. Culture medium from 94 was tested, in a dowble antibody precipitation test, for its capacity to bind the labelled protein contained in partially purified medium. Three IgG hybridomas gave positive results and one was cloned and used to produce ascites in BALB/c mice. Ascites IgG, used as first ant ib ody in a dowble antibody precipitation test, precipitated the labelled protein and removed anti-müllerian activity from medium containing bioactive AMH. The monoclonal antibody also blocked anti-müllerian activity of calf fetal testicular tissue, indicating that it is directed against the biologically active portion of the AMH molecule. These results prove the identity between AMH and its biochemical marker, and should greatly hasten the isolation and quantitative assay of the hormone.

\section{F.J.HOLLAND, D.DABATTISTA* and L.LUNA*}

Hospital for S1ck Children, U of Toronto, Canada Somatomedin in the rhesus monkey fetus

To assess the role of somatomedin in the maturing fetus, RIA was developed for Multiplication Stimulating Activity (MSA), a major soms tomedin. Purifled MSA was conjugated to hemocyanin and specific antiserum induced in rabbits. In the RIA there was parallel displacement with unlabelled MSA and acid-extracted human or rhesus monkey serum. There was no cross-reactivity with physiological concentrations of insulin or with the other somatomedins. Immunoreactive MSA(I-MSA) in acromegalic serum extracts was approximately twice that of normal controls, while levels were reduced in growth hormone (GH) deficlency. I-MSA in pooled extracts from sera of 5 adult male monkeys was $84.0 \mathrm{ng} / \mathrm{ml}$. Petal samples were obtained from rhesus monkeys through catheterized interplacental vessels. At 90 days gestation (term 165 days), I-MSA in 5 fetuses was $70.2 \pm 21.0 \mathrm{ng} / \mathrm{ml}$ (mean $\pm S B M$ ), and at 160 days, $172.0+34.3 \mathrm{ng} / \mathrm{ml}(\mathrm{P}<0.05)$. Correspoñding $\mathrm{GH}$ levels were $50.7 \pm 2.0 \mathrm{ng} / \mathrm{ml}$ and $24.3 \pm 2.3 \mathrm{ng} / \mathrm{ml}(\mathrm{P}<0.001)$ (reported 61st. End. Soc. 1979, Abst. 601). Because of marked variab1lity, the mean level of I-MSA in day-old neonates was not significantly different from fetal values. The rising levels of I-MSA during the latter half of gestation in these studies suggest that: (1) somatomedins may play an important role in fetal growth; (2) somatomedin may exert feedback inhibition on GH secretion during this period. Supported by MRC Canada Grant No 9360 . Lab. explorations fonctionnelles and INSERM U 142, Hôpi tal Trousseau, 75012 Paris, France.

IGF (insulin-like growth factor) levels in cases of idiopathic tall stature.

Serum ICF levels were assayed, after acid extraction, in $26 \mathrm{girls}$ and 32 boys (aged 1 - 22) whose height for their age exceed 3 SO, by a radioligand assay using human IGF ( $g 1 \mathrm{ft}$ from Dr Zapf, Zürich) and a specific binding protein produced by rat liver in culture. Results are expressed in relation to a pool of normal adult serum arbitrarily assigned a value of $1 \mathrm{U} / \mathrm{ml}$. 1) For the 15 children aged $1-10$, the mean ICF level was $0.83 \pm 0.09$ (SEM) $\mathrm{U} / \mathrm{ml}$ which is significantly higher than that for normal children $(0.59 \pm 0.05, n=29)$ $(p<0.01)$. 2) In the $2110-15$ year-old, ICF levels $(1.35 \pm 0.09)$ were higher than controls $(1.05 \pm 0.08, n=18)(p<0.01) .7$ girls and 1 boy had levels $(1.52-2.46)$ comparable to those of untreated acromegalics. $C H$ levels $60 \mathrm{mln}$ after glucose load $\left(30 \mathrm{~g} / \mathrm{m}^{2}\right)$ were $<5 \mathrm{ng} / \mathrm{ml}$ in 11 subjects studied. 3) In the 22 patients over 15 , ICF levels $(1.09 \pm 0.07)$ were similar to those of normal adults $(1.0$ $\pm 0.03 \mathrm{U} / \mathrm{ml})$. 4) In $10 \mathrm{glrls}$ under ettinyloestradiol $(200-300 \mu \mathrm{g} /$ day) for a prognosis of a final helght exceeding $180 \mathrm{~cm}$, parallel with the decrease in growth, there was a slow but progressive drop in ICF levels (means : $1.49 \mathrm{U} / \mathrm{ml}$ after 3 months, 1.08 after 1 year). The abnormally high IGF levels seen with Idiopathic tall stature and the drop accompanying oestrogen therapy suggest a direct relation between IGF production and growth rate. The return to normal levels once ossification is complete suggests a regulatory disorder during the growth period. 